\title{
An Aberrant Root Development in Severely Extruded Immature Young Permanent Tooth: A Case Report
}

\author{
Richa Kumari ${ }^{1}$, Neeraj Kumar ${ }^{2}$, Krishan Gauba ${ }^{3}$
}

\begin{abstract}
Trauma to immature teeth at younger age may result in number of developmental anomalies. Aberrant root development is a rare developmental anomaly reported in the literature thus far. A case of extrusive luxation of immature young permanent central incisor is presented which was repositioned and splinted using suture and semi-rigid wire composite splint. The luxated tooth showed almost complete root development till the root apex. Radiographic and clinical evaluation was done at regular intervals. This case report highlights the management of severely extruded immature young permanent tooth and ability of Hertwig's epithelial root sheath (HERS) to withstand the trauma effects and helps in root development.
\end{abstract}

Keywords: Extrusive luxation, Hertwig's epithelial root sheath, Immature permanent tooth, Root development.

Journal of South Asian Association of Pediatric Dentistry (2020): 10.5005/jp-journals-10077-3047

\section{INTRODUCTION}

Dental traumatic injuries have higher prevalence among the children aged 7-12 years. ${ }^{1}$ The most affected teeth are the upper maxillary central incisors that are erupting and have a periodontal ligament with minimal resistance to an extrusive force and a thin buccal alveolar plate. It has been reported that approximately $35 \%$ of all avulsions occur before the age of 9 , i.e., usually before full incisor root development, where the effects of traumatic injury can be very destructive. ${ }^{2}$ It is currently known that the healing process after traumatic dental injury is very complex, involving multiple and different types of cells (pulp, periodontal ligament, and alveolar bone) with different healing potentials. ${ }^{3}$ Accordingly, there are two possible healing scenarios after dental trauma: tissue regeneration and tissue reparation. The former is a biological process where the new tissue restores structure and function, whereas the second involves the formation of a nonfunctional scar tissue. ${ }^{4}$ The great variability of cells that participate in posttrauma healing, that is after extrusive luxation and replantation of avulsed permanent teeth, may explain the different clinical and imaging results during monitoring and follow-up.

In immature young permanent teeth, the Hertwig's epithelial root sheath (HERS) is usually sensitive to trauma; however, in some circumstances, it may resist damage from trauma or infection. This case report highlights the timely intervention of severely extruded left immature maxillary permanent incisor that shows aberrant root development, obliterated pulp space with tooth in position, and maintaining the functional and esthetic demands with long-term follow-ups.

\section{Case Description}

An 8-year-old girl child presented with dental injury in upper front tooth region due to fall on the ground while playing in school. The parents went to the local practitioner, where tetanus toxoid was given to the child and was referred to the specialist. The time elapsed between the dental injury and the treatment rendered was 2 hours. Past medical and dental history was insignificant. Extraoral examination revealed slight swelling and laceration on

\footnotetext{
1,3 Unit of Pedodontics and Preventive Dentistry, Oral Health Sciences Centre, Postgraduate Institute of Medical Education and Research, Chandigarh, India

2Department of Dentistry, Government Medical College Khandwa, Madhya Pradesh, India
}

Corresponding Author: Neeraj Kumar, Department of Dentistry, Government Medical College Khandwa, Madhya Pradesh, India, Phone: +91 9855344680, e-mail: dr.neeraj001@gmail.com

How to cite this article: Kumari R, Kumar N, Gauba K. An Aberrant Root Development in Severely Extruded Immature Young Permanent Tooth: A Case Report. J South Asian Assoc Pediatr Dent 2020;3(2):84-87.

Source of support: Nil

Conflict of interest: None

the upper lip. Intraoral examination showed that the dentition was in the mixed dentition stage, and maxillary left permanent incisor, that is 21 , was severely extruded. Gingiva was also lacerated with respect to 21 . Intraoral radiographs revealed 11 and 21 were in the Nolla's stage 7 and no bony support in relation to 21 (Fig. 1). The permanent right maxillary incisor was also in the erupting stage. The rest of the teeth appeared normal for her age with no sign of fracture. The patient and the parents were counseled about the importance of tooth, as the parents were anxious. The parents were told about the treatment plan and prognosis of the tooth. The parent consent was obtained, and treatment was rendered to the patient. Local anesthesia ( $2 \%$ Lignocaine with adrenaline) was administered, and the tooth was repositioned and stabilized with 3-0 Silk suture around the tooth, and flexible wire was used to splint the teeth with composite resin (Filtek Z350 XT; 3M ESPE, Sumaré, SP, Brazil) (Fig. 2). The patient was told to maintain the oral hygiene and advised to take soft diet for 2-3 weeks. Antibiotics and analgesics were also prescribed to the patient. Composite wire splint was removed after 4 weeks, and fixed retainer was given as there was no periodontal support around the tooth. There was no pulp response after 1 month in the traumatized tooth. The patient was followed up at regular intervals at 6,12 and 18 months with clinical and

() The Author(s). 2020 Open Access This article is distributed under the terms of the Creative Commons Attribution 4.0 International License (https://creativecommons. org/licenses/by-nc/4.0/), which permits unrestricted use, distribution, and non-commercial reproduction in any medium, provided you give appropriate credit to the original author(s) and the source, provide a link to the Creative Commons license, and indicate if changes were made. The Creative Commons Public Domain Dedication waiver (http://creativecommons.org/publicdomain/zero/1.0/) applies to the data made available in this article, unless otherwise stated. 

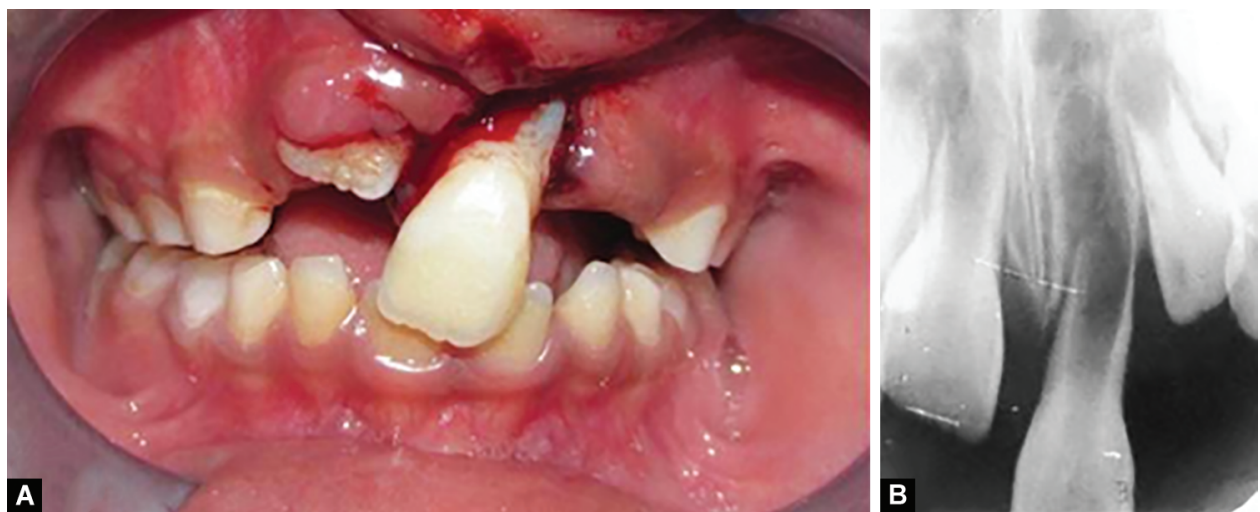

Figs $1 \mathrm{~A}$ and $\mathrm{B}$ : Clinical presentation (A) and preoperative intraoral periapical radiograph; (B) of extrusively luxated left permanent central incisor at the time of injury
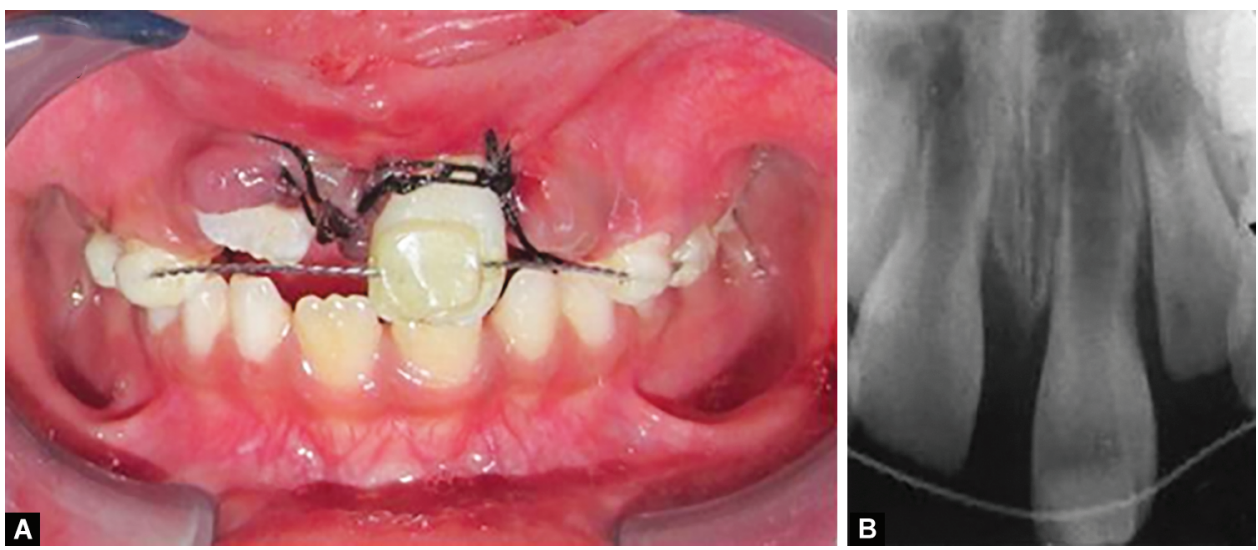

Figs $2 \mathrm{~A}$ and B: Intraoral photograph (A) and postoperative intraoral periapical radiograph; (B) after repositioning and stabilization with 3-0 silk suture and composite wire splint
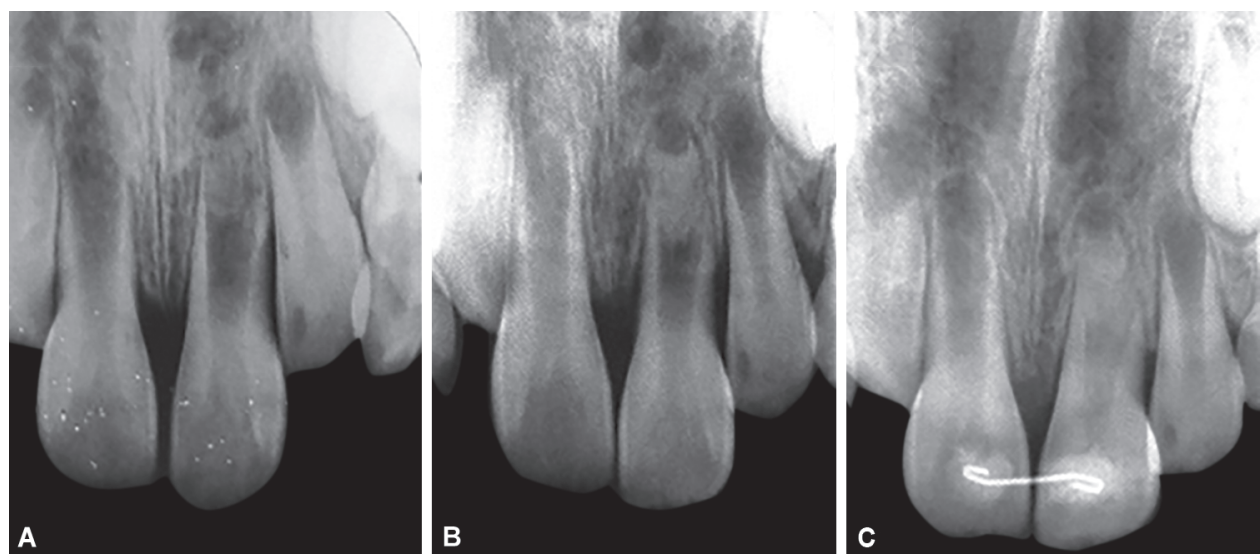

Figs 3A to C: Radiographic evaluation after (A) 6, (B) 12 and (C) 18 months showing root development with ingress of bony tissue

radiographic evaluation. After the 6 months, pulp vitality testing was done, and the tooth showed positive pulp response. During radiographic follow-ups, the tooth showed root development from the cervical third of the root (Fig. 3). The root showed breach in the cervical and middle third with ingress of bony tissue into the pulp space. After 24 months of follow-up, the tooth showed root development in the apical direction (Fig. 4). The root development occurs which was inconsistent with the right maxillary central incisor after 48 months of follow-up (Fig. 5). The almost complete root development occurred with obliterated pulp space, despite severe extrusive luxation injury during the follow-ups.

\section{Discussion}

Dental traumatic injuries occur more frequently in the primary dentition, and coronal fractures are more common in permanent dentition. In cases of young permanent teeth, the traumatic injuries that can affect root development are avulsion, extrusive luxation, and intrusive luxation. However, root development of permanent incisors may also be affected by the procedure of reimplantation and/or tooth reposition. ${ }^{5}$ The HERS, cells of dental papilla and dental follicle-like odontoblasts, cementoblasts, and the apical vascular bundle play important role in root formation. After the crown formation of tooth, the HERS grows in an apical direction between 

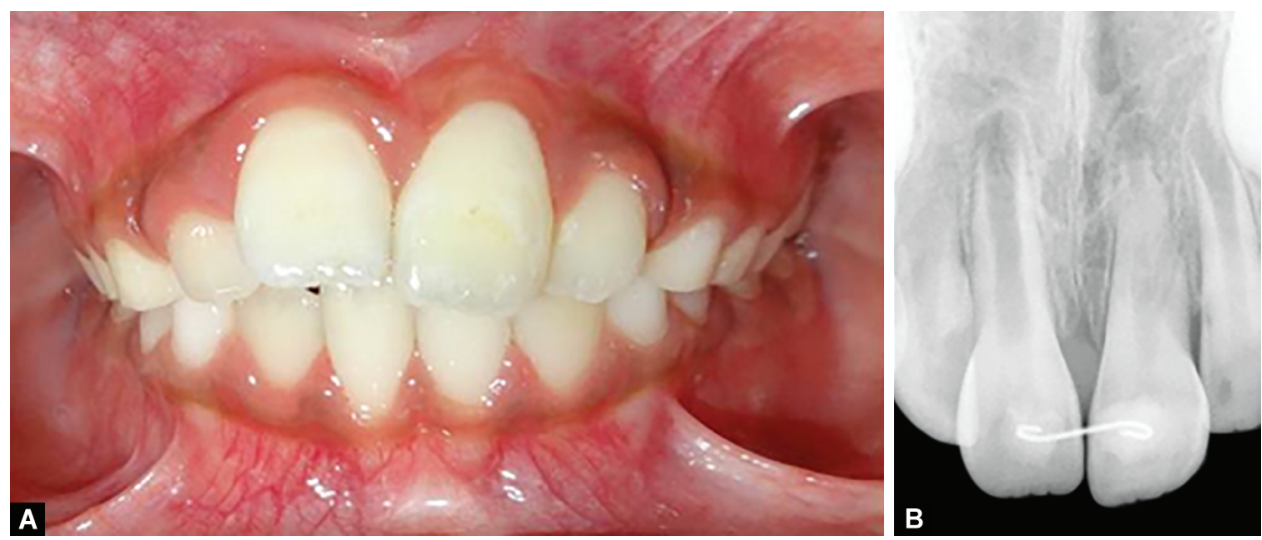

Figs 4A and B: Intraoral photograph (A) and radiographic presentation (B) after 24 months of follow-ups
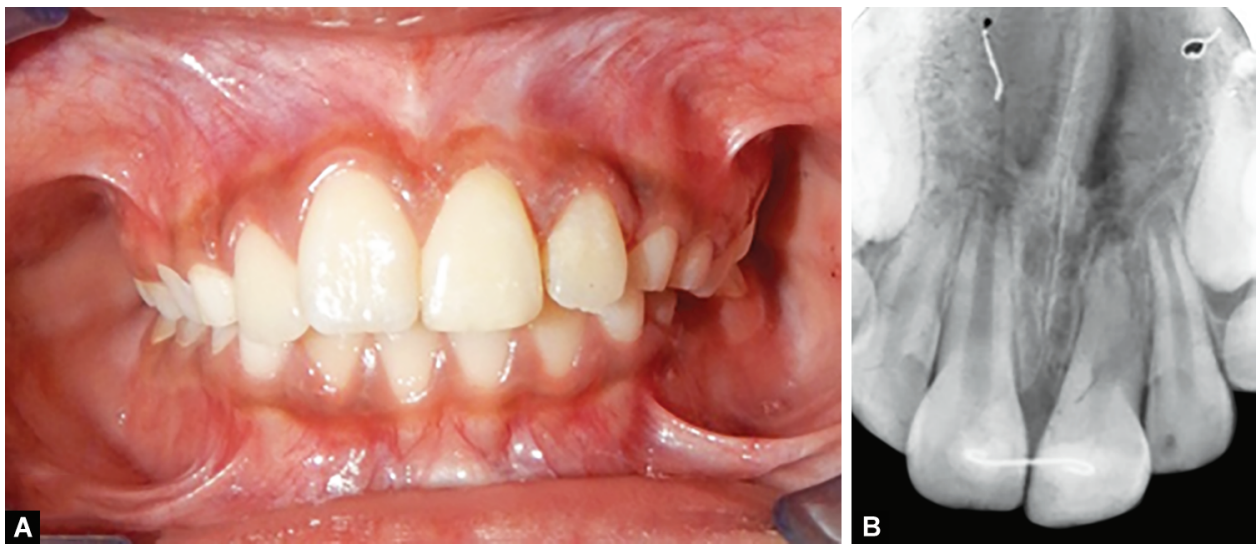

Figs $5 \mathrm{~A}$ and B: Intraoral photograph (A) and radiographic evaluation (B) after 48 months of follow-ups

the dental papilla and the dental follicle. ${ }^{6}$ The cells of the dental papilla adjacent to HERS get differentiated to form odontoblasts that form the radicular dentin. Various inducers such as laminin and transforming growth factor $\beta$ cause differentiation of dental papilla cells to odontoblasts. ${ }^{7}$ If the continuity of HERS is disturbed, the cells of the dental papilla fail to get differentiated into odontoblasts, and hence dentin formation will be affected. Subsequently, the cementum formation will also be affected.

There are four different cell populations that may respond to the traumatic injury in immature tooth during root formation, namely, cells of the pulp and apical zone, periodontal ligament, alveolar bone, and cells of the HERS. ${ }^{8}$ Dental trauma, surgical repositioning, or infection during the tooth development causes various crown and root anomalies such as hypoplastic defects in crown, dilaceration of root, and unusual/aberrant root development. ${ }^{9}$

Radiographically, root development can be classified into complete development, partial completion, and total arrest. In young immature permanent teeth, the HERS is usually sensitive to trauma or infection; however, in some circumstances, it may resist damage and continue root development irrespective of the morphological changes. ${ }^{10}$

Aberrant root development in case of extrusive luxation with 48 months follow-up has not been reported previously. In the present case, the traumatized tooth was repositioned and stabilized for 4 weeks and healed with almost compete root development. This could be due to the early intervention by the pediatric dentist and resilient nature of the HERS which withstand the trauma effect to complete the odontoblastic differentiation and root formation in the rest of the tooth root except in the region of perforation where there is a lack of dentin and cementum. ${ }^{11}$

According to International Association of Dental Traumatology guidelines, splinting should be recommended for 2 and 4 weeks for extrusive and lateral luxation, respectively. ${ }^{12}$ Considering poor prognosis in this case, splitting was done for 4 weeks and later on fixed retainer to provide support, as the adjacent tooth was in the eruption phase. An immature tooth has an excellent capacity to recover during the developmental period. The complications related to the healing of the periodonium in the extrusive and lateral luxation injuries are generally low. Marginal bone boss and repairrelated resorption occur more significantly in the teeth with mature root development and injuries involving the multiple teeth. ${ }^{13}$

\section{Conclusion}

Aberrant root development is a rare complication after the dental trauma in young immature permanent tooth. Patient's age, psychological, functional, and esthetic factors are taken into consideration before any invasive procedures. Long-term clinical and radiological follow-ups would be needed in cases of immature traumatized teeth. Hertwig's epithelial root sheath acts as a reservoir of undifferentiated cells that may resist trauma or infection and performs its function of root development in young immature permanent tooth. 


\section{LiMITATIONS}

- Histological studies need to be carried out to justify the role of the different cells in the root development of traumatized teeth.

- Long-term follow-up would be needed in immature traumatized teeth.

\section{ACKNOWLedgment}

The authors want to acknowledge that the present case was managed at Postgraduate Institute of Medical Education and Research, Chandigarh. The details related to the present case were not copied from any other sources.

\section{References}

1. Glendor U. Epidemiology of traumatic dental injuries- a 12 year review of the literature. Dent Traumatol 2008;24(6):603-611. DOI: 10.1111/j.1600-9657.2008.00696.x.

2. Andreasen JO, Borum MK, Andreasen FM. Replantation of 400 avulsed permanent incisors. 3. Factors related to root growth. Endod Dent Traumatol 1995;11(2):69-75. DOI: 10.1111/j.1600-9657.1995.tb00463.x.

3. Andreasen JO, Andreasen FM, Andersson L. Textbook and Color Atlas of Traumatic Injuries to the Teeth. 4th ed., Hoboken: Wiley; 2013.

4. Bourne GH, Wilson EMH. Structural Aspects of Aging. New York: Hafner Publishing Company Inc; 1963.

5. Andreasen JO, Bakland LK. Pulp regeneration after non-infected and infected necrosis, what type of tissue do we want? a review.
Dent Traumatol 2012;28(1):13-18. DOI: 10.1111/j.1600-9657.2011. 01057.x.

6. Andreasen JO. Pulp and periodontal tissue repair-regeneration or tissue metaplasia after dental trauma. A review. Dent Traumatol 2012;28(1):19-24. DOI: 10.1111/j.1600-9657.2011.01058.x.

7. Thomas HF. Root formation. Int J Dev Biol 1995;39(1):231-237.

8. Huang XF, Chai Y. Molecular regulatory mechanism of tooth root development. Int J Oral Sci 2012;4(4):177-181. DOI: 10.1038/ ijos.2012.61.

9. Andreasen JO, Kristerson L, Andreasen FM. Damage of the Hertwig's epithelial root sheath: effect upon root growth after autotransplantation of teeth in monkeys. Dent Traumatol 1998;4(4):145-151. DOI: 10.1111/j.1600-9657.1988.tb00313.x.

10. Bhatia SK, Goyal A, Gauba K, et al. Unusual root development following surgical repositioning of horizontally developing central incisor. Dent Traumatol 2015;31(5):413-417. DOI: 10.1111/edt.12182.

11. Andreasen JO, Lovschall $\mathrm{H}$. Response of oral tissues to trauma. In: Andreasen JO, Andreasen FM, Andersson L. Textbook and Color Atlas of Traumatic Injuries to the Teeth. 4th ed., Munksgaard: Blackwell; 2007. 62-113.

12. DiAngelis AJ, Andreasen JO, Ebeleseder KA, et al. International association of dental Traumatology guidelines for the management of traumatic dental injuries: 1. Fractures and luxations of permanent teeth. Dental Traumatol 2012;28(1):2-12. DOI: 10.1111/j.16009657.2011.01103.x

13. Hermann NV, Lauridsen E, Ahrensburg SS, et al. Periodontal healing complications following extrusive and lateral luxation in the permanent dentition: a longitudinal cohort study. Dent Traumatol 2012;28(5):394-402. DOI: 10.1111/edt.12000. 